\title{
Dietrich Bonhoeffer, Nelson Mandela and the dilemma of violent resistance in retrospect $^{1}$
}

\author{
De Gruchy, John W \\ University of Cape Town \\ john@degruchy.co.za
}

\begin{abstract}
Nelson Mandela and Dietrich Bonhoeffer have become twentieth century icons of resistance against illegitimate regimes and oppression. Both of them were committed makers of peace who were forced by circumstances to engage in violent resistance, the one in an armed struggle and the other in a plot to assassinate a dictator. This recourse to violent means in extraordinary circumstances was driven by moral and strategic considerations that followed a similar logic, even though their contexts were different in important respects. In this essay, we explore these similarities and differences, as well as their reasons for engaging in violent action, and offer certain propositions based on their narrative for responding to political oppression and the call for regime change today.
\end{abstract}

\section{Keywords}

Nelson Mandela, Dietrich Bonhoeffer, violent resistance, armed struggle, Church struggle

The Seventh International Bonhoeffer Congress was held in Cape Town in January 1996. It was appropriate that the venue was formerly a prison and that some of the seminars were held in its cells. Congress participants also visited Robben Island, infamous as the chief security prison of the apartheid regime and home to Nelson Mandela for much of his twentyseven years behind bars. The visit was an emotional experience, prompting comparative reflection on Dietrich Bonhoeffer and Mandela - two of the most celebrated prisoners of the twentieth century.

1 This article is based on a paper which I gave at a Conference on 'Bonhoeffer's Dilemma: The Ethics of Violence', Penn State University, October 28-31, 1999. It has been reworked and revised for publication in the light of current developments. 
Obvious similarities linking the inmates in Cell 92 of Berlin's Tegel Prison and the cramped cell on Robben Island immediately came to mind. Bonhoeffer's significance for the struggle against apartheid also found a fresh focal point as we pondered the fate of these two heroic and seminal figures of resistance against oppression. The one a martyr who was put to death at the command of Adolf Hitler, the other a joint Nobel Peace Prize winner with his erstwhile enemy, FW de Klerk, for negotiating a peaceful transition to democracy after a protracted violent struggle.

Now, more than twenty years after the ending of apartheid and the birth of the new democratic South Africa, the question is re-emerging as to whether the "negotiated revolution" ${ }^{2}$ was as successful as is usually claimed. ${ }^{3}$ The fact that Mandela gave up the armed struggle in favour of a negotiated settlement with the apartheid regime has come under scrutiny once more by those who believe that it involved too much compromise with white and neo-colonial capitalist interests. ${ }^{4}$ There is even, at least among some radical younger black South Africans, talk about returning to violent means to achieve genuine transformation. It is with this in mind that I have revisited what I previously wrote at a time when few would have considered such a step either morally justifiable or politically necessary.

My specific focus in this essay remains the same, however, namely to compare the role of Mandela in the armed struggle against apartheid and Bonhoeffer's participation in the German resistance and the plot to assassinate Adolf Hitler. This requires, first of all, some comment on the similarities and differences that mark the role and fate of these two icons of twentieth century political resistance who resorted to violence as a last resort. I shall then consider the different ways in which they understood what they were doing in order to provide a basis for some concluding reflections on the perennial challenge that such icons of political resistance present to us in our own time, not least today in South Africa more than

2 Adam Heribert and Kogila Moodley, The Negotiated Revolution: Society and Politics in Post-Apartheid South Africa (Berkeley, CA: University of California Press, 1993).

3 See Jeff Peires, 'Agony and Ecstasy at the End of the Rainbow,' South African Historical Journal vol. 61, no.1 (2009): 178-86.

4 Godson S. Maanga, 'The relevance and legacy of Nelson Mandela in the twenty-first century Africa: A historical and theological perspective,' African Journal of History and Culture vol. 5, no. 5 (2013): 96-113. 
twenty years after the transition to democracy in 1994. I begin with some comments on the similarities and differences between Mandela and Bonhoeffer, and their role in political resistance.

\section{Similarities and differences}

In reflecting on the lives of Mandela and Bonhoeffer, the following points of similarity come to mind. Both Mandela and Bonhoeffer were aristocrats. ${ }^{5}$ Mandela was the son of a Thembu chief; Bonhoeffer a child of Germany's cultural and intellectual elite. Mandela's commitment to the struggle against apartheid was deeply rooted in his African nationalist patriotism, his moral outrage against colonial injustice and racist oppression, and in his hope for the birth of a new South Africa. Bonhoeffer's engagement in the German resistance was equally driven by a deep patriotism and growing outrage at the Nazi persecution of the Jews.

Both Mandela and Bonhoeffer were engaged in fighting against totalitarian, racist and dehumanizing ideologies and regimes on behalf of their victims, even though Mandela was part of the oppressed while Bonhoeffer chose to identify vicariously with the Jews, the chief but not the only victims of Nazism. Both were dedicated peace-makers, committed to the prevention of conflict and war, yet both embarked on the path of violent resistance when all other alternatives seemed exhausted. Both were aware of the moral dilemmas that surrounded their decisions, giving considerable thought to the possible consequences, but reluctantly chose the path they did, accepting the risks involved.

The obvious differences are those of culture and historical context. Mandela was a son of the African soil and Bonhoeffer a product of Germany's Bildungsbürgertum, each living at a specific moment of national crisis and destiny. There were also differences of education, vocation, religious commitment and the extent and nature of their political involvement. Mandela was a lawyer by training, and a political leader within the African National Congress (ANC), a mass non-violent nationalist resistance movement. Bonhoeffer was a pastor and theologian by training, a servant

5 For biographical details, see Nelson Mandela, Long Walk to Freedom: The Autobiography of Nelson Mandela (Johannesburg: Macdonald Purnell, 1994) and Eberhard Bethge, Dietrich Bonhoeffer: A Biography (Minneapolis: Fortress Press, 2000). 
of the church, albeit critically located on its boundaries. And although politically engaged and supportive of the social democrats, he was not a member of the Party.

Mandela's decision to engage in an armed struggle was a corporate one, the decision of the leadership of the ANC, and one which gained the support of the movement as a whole. Although there were many Christians involved in the ANC, it was a nationalist movement of liberation whose goal was the formation of an ethnically inclusive democracy and therefore the establishment of a new order of peace and justice guided by its Freedom Charter. ${ }^{6}$ In Bonhoeffer's case it became impossible to be a nationalist and a Christian; in South Africa, many Christians were members of the ANC, as were its founding fathers and mothers. Being part of the African nationalist struggle was, for many people, part of what it meant to be a Christian. In fact, unlike in Germany, in South Africa the church struggle became an integral part of the liberation struggle, especially after the Soweto uprising in 1976. It is really here, at the interface of church and political resistance that Bonhoeffer's legacy was most significant as can be seen from the way in which he influenced a person like Beyers Naudé, the Dutch Reformed pastor who founded the Christian Institute. ${ }^{7}$

Although Mandela was a product of missionary education and shaped by Christian moral values, his political philosophy was chiefly determined by African cultural tradition, Western democracy and Marxism, woven together in the struggle against racist oppression. ${ }^{8}$ On my reckoning, he was, however, a Christian humanist in the broad sense of the term, a description which applies to Bonhoeffer as well. ${ }^{9}$

6 See inter alia, Francis Meli, A History of the ANC: South Africa Belongs to Us (Harare: Zimbabwe Publishing House, 1988), 123-27.

7 John W. de Gruchy, 'Beyers Naudé: South Africa's Bonhoeffer? Celebrating the centenary of the birth of Beyers Naudé - 1915-2015, 'Stellenbosch Theological Journal vol. 1, no. 1 (2015): 79-98.

8 See also Nelson Mandela, The Struggle is My Life: His Speeches and Writings Brought Together with Historical Documents and Accounts by Fellow Prisoners (London: IDAF Publications, 1990). On Mandela and Methodism see Dion Foster, 'Mandela and the Methodists: faith, fallacy and fact,' Studia Historiae Ecclesiasticae 40, Supplement (2014):87-115.

9 See John W de Gruchy, Being Human: Confessions of a Christian Humanist (London: SCM, 2006), 29, 192-3 and John W de Gruchy, 'Dietrich Bonhoeffer as Christian 
Significantly, their differences also extend to their respective arrests, trials, and destiny. Mandela was formally tried in a court of law where he made a remarkable speech from the dock outlining for the world the reasons for African resistance and the necessity of recourse to arms. I shall return to this speech later. He was found guilty of treason but avoided the gallows and was imprisoned for twenty-seven years of hard labour. During that time, he was surrounded by his comrades, and his stature as a leader and hero of the anti-apartheid struggle grew to such an extent that he became the focal point and icon of resistance and liberation. From prison he eventually prepared the way for the negotiated revolution which led to the birth of the new South Africa. Mandela walked out of prison a free man, reunited with his family and friends. He became the President of South Africa, a renowned world statesman, and a moral leader in the cause of justice and peace.

By contrast Bonhoeffer was part of a small group of conspirators drawn from an elite whose plans to assassinate Hitler failed disastrously. All of the conspirators were convicted of treason, imprisoned, and murdered by the Gestapo before the liberation of their country. Bonhoeffer was a prisoner for less than two years before his ignominious death in Flossenberg concentration camp. There was no 'walk to freedom', only 'Stations on the Road to Freedom' which ended naked on the gallows. ${ }^{10}$ There was no reunion with fiancé, family or friends. His posthumous status in post-war Germany was that of a prophet without honour. In fact, in 1956 the Federal Court exonerated his executioners on the grounds that they were acting legally in respect of treason, a decision that was only overturned in $1995 !^{11}$ Moreover, there is considerable ambivalence within the Jewish community as to whether he can rightly be counted among the 'righteous gentiles' even though his arrest was due to his aiding Jews to escape the Third Reich. ${ }^{12}$

Humanist.' In Being Human, Becoming Human: Dietrich Bonhoeffer and Social Thought, eds. Jens Zimmerman and Brian Gregor (Eugene, Oregon: Pickwick Press, 2010), 3-24.

10 Dietrich Bonhoeffer, Letters and Papers from Prison, Dietrich Bonhoeffer Works vol. 8, ed. John W. de Gruchy (Minneapolis: Fortress Press, 2010), 512-14.

11 John A Moses, 'Dietrich Bonhoeffer as Conspirator Against the Hitler Regime: The Motivation of a German Protestant Revolutionary,' War and Society 17, no. 1 (1999): 28, n. 8 .

12 See David P. Gushee, The Righteous Gentiles of the Holocaust: A Christian Interpretation (Minneapolis: Fortress, 1994), 130-132. 
So we come to the key question: how did they themselves understand what they were doing when they embarked on the risky course of action that determined their fate?

\section{The ambiguous road from nonviolence to armed struggle}

On October $9^{\text {th }}, 1963$, Mandela appeared with nine compatriots in the Pretoria Supreme Court accused of embarking on a campaign to overthrow the government by violent revolution. On April $20^{\text {th }}$ the following year, Mandela, who refused to give evidence in his own defence or be crossexamined, set out the reasons which led the ANC to embark on the armed struggle. His speech has become a classic text of twentieth century resistance against oppression.

Historically, the ANC since its founding in 1912 was committed to nonviolent resistance for two main reasons. The first was strategic. Born out of the ashes of repeated bloody attempts to repulse colonialism by military means, it was inconceivable that white domination could be challenged by a further recourse to arms. The second was moral. Its ethos was deeply influenced by Christian and democratic values. ${ }^{13}$ These factors, the one strategic the other moral, were at the heart of the dilemma facing the ANC when it embarked on the armed struggle.

Mandela began his 'Speech from the Dock' by outlining the history of the colonial and apartheid oppression of black South Africans over more than three hundred years. He recounted how the ANC had attempted by peaceful means to change the situation, only to be continually rebuffed. Peaceful resistance was met with increasing force and violent repression. Mandela then came to the decisive point:

It was only when all else failed, when all channels of peaceful protest were barred to us, that the decision was taken to embark on violent forms of political struggle... We did so not because we desired such a course, but solely because the government had left us with no other choice. ${ }^{14}$

13 See inter alia, R. Simangaliso Kumalo, Pastor and Politicians: Essays on the Legacy of JL, the First President of the African National Congress (Pietermaritzburg: Cluster, 2012); Albert Luthuli, Let my People Go! (London: Collins, 1962).

14 Mandela, 'Second Court Statement, 1964'. In The Struggle is My Life, 168. 
So it was that on 16 December 1961, an auspicious date in South Africa's political calendar, ${ }^{15}$ the ANC decided the time had come 'to hit back by all means in our power in defence of our people, our future, and our freedom.' In line with that corporate strategic decision, Mandela felt 'morally obliged to do what he did.' This rationale and its embodiment in the 'will of the people' is of considerable importance if we are to understand the history and ethos of the armed struggle in comparison with the German Resistance and Bonhoeffer's role in it. ${ }^{16}$

Four forms of violent resistance were possible and each was considered by the ANC leadership: sabotage, guerrilla warfare, terrorism, and open revolution. Because the sabotage of strategic military and para-military targets would be the least destructive in terms of human bloodshed, that was the preferred path. This was a moral decision. But the ANC leadership was aware that sabotage alone might not bring the apartheid regime to its knees. It might even strengthen its resolve to repress resistance which, in fact, proved to be the case. So a further decision was taken 'to make provision for the possibility of guerrilla warfare. ${ }^{17}$ This led Mandela to leave the country in order to study 'the art of war and revolution' in Algeria. 'If there was to be guerrilla warfare,' he declared, he 'wanted to be able to stand and fight with my people and share the hazards of war with them. ${ }^{\text {'18 }}$ This also enabled him to start the process of recruiting other South Africans for military training.

One of the remarkable aspects about the ANC decision to resort to armed resistance was the extent to which its leadership went to ensure that acts of violence were, to quote Mandela, 'properly controlled.' Hence their insistence that they were only to be undertaken by the military wing of the ANC, Umkhonto we Sizwe ('Spear of the Nation'). There was an acute awareness of the dangers of an all-out civil war that would lead to a spiral of violence and the possible destruction of South Africa rather than the

1516 December is the date on which Boer trekkers routed the Zulu army at the Battle of Blood River in 1838. This event was later regarded as the formative moment in the rise of Afrikaner Nationalism, and celebrated as the 'Day of the Vow'.

16 On the German Resistance, see Karl Dietrich Bracher, The German Dictatorship: The Origins, Structure and Consequences of National Socialism (London: Penguin Books, 1973), 533-68.

17 Mandela, 'Second Court Statement, 1964,' The Struggle is My Life, 169.

18 Mandela, 'Second Court Statement, 1964,' The Struggle is My Life, 171. 
birth of a non-racial, just democratic order. The decision to engage in violent resistance was thus strategically far-sighted, taking account of long term consequences. This was central to the moral dilemma facing the ANC in taking this step. The cycle of violence triggered off by colonial conquest had to be broken rather than perpetuated. The armed struggle was a peacemaking strategy made necessary by violent repression. So Mandela brought his speech in the dock to a conclusion with these words:

The ANC has spent half a century fighting against racialism. When it triumphs it will not change that policy. This then is what the ANC is fighting. Their struggle is a truly national one. It is a struggle of the African people, inspired by their own suffering and their own experience. It is a struggle for the right to live. During my lifetime I have dedicated myself to this struggle of the African people. I have fought against white domination, and I have fought against black domination. I have cherished the ideal of a democratic and free society in which all persons live together in harmony and with equal opportunities. It is an ideal I hope to live for and achieve. But if needs be, it is an ideal for which I am prepared to die. ${ }^{19}$

Less than a year after Mandela's speech from the dock, ZK Matthews, another distinguished ANC leader but also a leading Christian ecumenist, addressed a conference convened by the World Council of Churches to consider the role of the ecumenical church in the struggle for justice in southern Africa. This conference, held in Zambia, was a watershed moment in the history of the ecumenical movement because it prepared the way for the launching of the Programme to Combat Racism five years later. ${ }^{20}$ The significance of Matthew's speech, entitled 'The Road from Nonviolence to Violence', was the fact that he took the decision of the ANC to resort to the armed struggle and turned it into a challenge to the church.

'The dilemma confronting A frican leaders' Matthews declared, was 'whether they should continue to urge their followers to stand by their methods of persuasion and discussion in the face of increasing and relentless force with which their attempts at the amelioration of their lot are met by the government.' With convincing rhetoric Matthews continued:

19 Mandela, 'Second Court Statement, 1964,' The Struggle is My Life, 181.

20 John W de Gruchy with Steve de Gruchy, The Church Struggle in South Africa: 25 ${ }^{\text {th }}$ Anniversary Edition (London: SCM, 2004), 123-34. 
When the flower of African youth represented by men such as Mandela or Dr Alexander are being sentenced to long terms of imprisonment during peace time, for fighting for their legitimate rights in what they believe to be the only ways open to them, can we say that the Christian thing to do is to advise them to acquiesce in their present situation and wait, Micawber-like, for something to turn up? ${ }^{21}$

These graphic words summed up the challenge then facing the ecumenical church in South Africa and further afield at that critical historical moment. Mandela's challenge to the apartheid regime and more generally to white South Africa was now specifically aimed by Matthews at the church itself. How the churches responded to this challenge would determine their role in the church struggle in South Africa that was then unfolding. ${ }^{22}$

There has been considerable debate about the significance of the armed struggle in bringing the apartheid regime to its knees. It was, after all, some say, only part of the liberation struggle, a struggle comprising many other non-violent acts of resistance like sanctions. Was the armed struggle necessary? Was it more than a symbolic gesture? Did it, in fact, contribute to a climate of violence that continues to plague South Africa? However we answer those questions, it is evident in hindsight that Matthew's challenge to the ecumenical church in response to the armed struggle was a decisive turning point in the church's participation in the struggle against apartheid. And it is precisely at this point that Bonhoeffer's legacy becomes pertinent for our discussion. For this was the context within which Bonhoeffer's example began to influence the church struggle in South Africa. Bonhoeffer's example was even quoted in Parliament in defence of those Christians who engaged in acts of resistance to apartheid. ${ }^{23}$

21 Published in Thomas G. Karis and Gail M. Gerhart, A Documentary History of African Politics in South Africa, 1882-1990: Nadir and Resurgence, 1964-1979, From Protest to Challenge, vol. 5 (Pretoria: Unisa Press, 1997), 356.

22 See De Gruchy, The Church Struggle in South Africa, 123-34.

23 On the role of Bonhoeffer's influence in South Africa, see Bonhoeffer for a New Day: Theology in a Time of Transition, ed. John W. de Gruchy (Grand Rapids: Eerdmans, 1997), $353 \mathrm{ff}$. 


\section{From confession to resistance}

There are two major texts in Bonhoeffer's writings that help us understand his rationale for joining the German resistance. The first on 'The Church and the Jewish Question' was written in 1933 in response to Hitler's Aryan legislation (Civil Service Reconstruction Law). ${ }^{24}$ The second, on 'The Structure of Responsible Life,' forms part of his posthumously compiled Ethics. ${ }^{25}$ If the first essay anticipates Bonhoeffer's later decision to engage in the resistance on the basis of a Reformation approach to church and state relations, the second essay provides us with an insight into Bonhoeffer's theological struggle on the boundaries of ethical decision-making in highly ambiguous situations.

These two essays, the one at the beginning of the German Kirchenkampf and the other as Bonhoeffer became directly involved in the conspiracy in 1941, indicate a shift no less decisive than that made by the ANC and Mandela in turning from non-violence to violent resistance. Yet it was a shift already prefigured when, in describing the three phases of church resistance to unjust government in the essay on 'The Church and the Jewish Question,' Bonhoeffer declared that the time might come when it was necessary to engage directly in political action and 'put a spoke in the wheel' of the state, or more accurately translated, 'to seize the wheel itself.'26 Either way it means bringing state terror to a halt. ${ }^{27}$

Virtually all German theologians at the time regarded Bonhoeffer's statement as far too radical, even though, for Bonhoeffer, it was based on a Reformation understanding of true leadership and government, not on liberal democratic reasoning. The fundamental difference between Bonhoeffer and other theologians who were likewise concerned about the rise of Nazism, was that Bonhoeffer was already questioning the legitimacy of the state on the grounds that its actions were undermining the rule of law. The possibility of direct political action on the part of Christians,

24 Dietrich Bonhoeffer, Berlin 1932-1933, Dietrich Bonhoeffer Works, vol. 12, ed. Larry L. Rasmussen (Minneapolis: Fortress), 361-70.

25 Dietrich Bonhoeffer, Ethics, Dietrich Bonhoeffer Works, vol. 6, ed. Clifford J. Green (Minneapolis: Fortress, 2005), 257-89.

26 Bonhoeffer, Berlin 1932-1933, 365-6.

27 See fn.12 Bonhoeffer, Berlin 1932-1933, 365. 
action which might even require violence, was a response to state terror. This was, in effect, the same rationale used by the ANC twenty years later.

Although it could be argued that Hitler finally achieved power through constitutional means, it is equally true that he seized power through violence. This pseudo-legitimacy created the ambiguity facing those who, from a traditional theological perspective, tried to respond. In similar vein, the National Party apartheid government could claim to be the legitimate government of South Africa as recognized by the United Nations, and it was so regarded by the United States, Britain, France and Germany, to mention only these major powers who also considered Mandela a 'terrorist.' And yet, from the perspective of the majority in South Africa, the apartheid regime was illegitimate. It was founded on the violent colonial subjugation of the indigenous peoples of the country; its maintenance of power required the increasing use of violence; and despite its claim to be protecting 'law and order', it was actually destroying it. This was the logic that led the shift in ANC policy from non-violent resistance alone to the armed struggle. It was also the logic that led to Bonhoeffer's conclusion that the wheel of the German nation had to be seized by force if necessary.

However, in his essay on 'The Church and the Jewish Question', Bonhoeffer's focus was on the role of the church, not on a political party or organization in combating state terror. It was only when the vast majority of the pastors of the Confessing Church, that is, the dissident Church opposed to Hitler, took the oath of allegiance to Hitler at the outbreak of war, thereby giving the state legitimacy, that Bonhoeffer engaged in what he called his act of 'free responsibility' and joined the conspiracy to assassinate Hitler. ${ }^{28} \mathrm{His}$ decision was both an ethical and a strategic one. Morally not to act in such a way was worse than committing such a violent deed. Strategically there seemed to be no alternative to ending the war and Nazi terror other than through killing Hitler. On both accounts, there was a need to go beyond the church struggle and enter directly into the political arena.

Unlike the ANC's decision to engage in an armed struggle, Bonhoeffer's espousal of violent resistance was aimed at one person, even though the moral argument was similar. Treason was justified when law and order

28 Bonhoeffer, Ethics, 79. 
had been destroyed by the regime itself. ${ }^{29}$ There was also the conviction among the conspirators that the assassination of Hitler would lead almost immediately to the collapse of the Nazi control of Germany and the ending of the war. ${ }^{30}$ The killing of an individual could therefore save millions of others from death. This was much like the 'regime change' policies of more recent times which assume that getting rid of a dictator will result in the liberation of the nation from tyranny.

In South Africa this was simply not a possibility. The assassination of Prime Minister Verwoerd in Parliament in September 1966 'left no political vacuum and hardly caused a hiatus in the continuity of government policy. ${ }^{31}$ Apartheid was not built around one Führer who embodied German nationalist aspirations, but on the selfish aspirations of one ethnic minority who had achieved power. So what Bonhoeffer (and his fellow conspirators) embarked on with his 'act of free responsibility' was not an armed struggle of liberation, such as in South Africa, but a very limited act of violence aimed at Hitler. The death of one man might have saved millions of lives. For patriotic Germans within the military, even those opposed to Nazism, such an act was unthinkable. The issue for them was not that of taking someone's life - they were mainly soldiers after all - but of breaking their word of honour. That was the moral dilemma facing the conspirators, and one reason why they welcomed pastor Bonhoeffer into their circle was to help them deal with it. It was partly with this in mind that Bonhoeffer wrote his essay 'After Ten Years' which Bethge made the Prologue to his Letters and Papers from Prison. ${ }^{32}$ Submissiveness and self-sacrifice, virtuous as they may be, can be exploited for evil ends. As Bonhoeffer told the conspirators, 'civil courage can grow only from the free responsibility of the free man. ${ }^{33}$

29 Bracher, The German Dictatorship, 538.

30 See Larry L. Rasmussen, Dietrich Bonhoeffer: Reality and Resistance (Nashville: Abingdon, 1972).

31 TRH Davenport, South Africa: A Modern History (Johannesburg: Macmillan South Africa, 1977), 294.

32 'An Account of the Turn of the Year 1942-1943: After Ten Years,' Bonhoeffer, Letters and Papers from Prison, 37-54.

33 Bonhoeffer, Letters and Papers from Prison, 41. 
Such thoughts on the eve of his arrest and imprisonment had long been gestating, especially in his reflections on 'The Structure of Responsible Life' which became central to this Ethics. Human beings are responsible to God for their actions, yet there are morally ambiguous situations in which they have to exercise their freedom. Not to do so would be irresponsible, but there is no guarantee that the act of free responsibility is untainted by sin. Truly responsible persons, acting freely, does so without the support of others or ethical absolutes. 'They themselves have to observe, judge, weigh, decide and act on their own. ${ }^{34}$ But such 'free action recognizes itself ultimately as being God's action, the decision as God's guidance, the venture as divine necessity. ${ }^{35}$

Bonhoeffer's reflections on the need to risk the venture of free responsibility would later become seminal in South Africa, no more so than in the drafting of the Kairos Document in 1986 which categorically rejected the apartheid regime as tyrannical, and unequivocally called on Christians to take sides with the oppressed in their struggle for justice. Although this reflected a long tradition in Christian ethics which insisted on Christian responsibility to oppose tyranny, ${ }^{36}$ it was Bonhoeffer's writings and his courageous action that inspired many to affirm the message of the Kairos Document.

A tyrannical regime cannot continue to rule for very long without becoming more and more violent. As the majority of people begin to demand their rights and to put pressure on the tyrant, so will the tyrant resort more and more to desperate, cruel, gross and ruthless forms of tyranny and repression. The reign of a tyrant always ends up as a reign of terror. It is inevitable because from the start the tyrant is an enemy of the common good. ${ }^{37}$

The corollary to stating that the South African regime was tyrannical was the call 'to eliminate the oppression, remove the tyrants from power and establish a just government for the common good of all the people. ${ }^{38}$ This could be, and was read by some, as giving implicit support to the armed

34 Bonhoeffer, Ethics, 282.

35 Bonhoeffer, Ethics, 284.

36 See de Gruchy, Bonhoeffer and South Africa, 91-122.

37 The Kairos Document (Johannesburg: Institute for Contextual Theology, 1986), 23.

38 The Kairos Document, 24. 
struggle. But in the end, the Kairos Document drew back from the brink of open support for taking up arms. Its call was for non-violent resistance. The same message was more clearly and unequivocally stated in the KairosPalestine Document which adopted the South Africa Kairos Document as its model. ${ }^{39}$

\section{Concluding propositions}

In this brief concluding section, I do not intend to rehearse the perennial debate around issues relating to just wars and revolutions, though these are implicit. My aim is rather to reflect on the Mandela and Bonhoeffer narratives in order to offer some propositions for discussion that are pertinent to the current debate about the use of violence in bringing about political or regime change. The misuse of Bonhoeffer's legacy by President George W Bush to justify the war in Iraq is only one example of the dangers involved.

\section{i) Responsible political action must be informed by vigorous critical social analysis and an in-depth consideration of the possible success and consequences of such action.}

Both Mandela and Bonhoeffer were committed to peaceful non-violent action. They only turned to the use of violence when all other options were closed off by the tyrannical violence of the state, and after intense weighing up of moral and strategic factors. Their decisions were specific to a particular historical context and cannot be used to provide legitimacy to do the same within different historical contexts, especially in democracies, even if corrupt. The critical issue is the total collapse of justice, law and order, and the tyrannical imploding of the state. But even then Bonhoeffer warned against the temptation of taking the field like Don Quixote without considering the realities facing us, as well as the possible consequences of our actions. There is, he wrote, nothing morally responsible about 'going down fighting like heroes in the face of certain defeat' and therefore not facing the future responsibly, that is, taking into serious account the

39 Kairos-Palestine: A Moment of Truth: A Word of Faith, Hope and Love from the Heart of Palestinian Suffering, [Online]. A document drafted by Palestinian Christians and endorsed by the Patriarchs and Heads of Churches in Jerusalem. Available: http://www. kairospalestine.ps/index.php/about-us/kairos-palestine-document [Accessed 19 July, 2016]. 
possible consequences of our actions for future generations. ${ }^{40}$ The fact is, once the path of violent resistance is chosen, forces are unleashed which are difficult to control and unintended destructive consequences become inevitable, such as the loss of innocent lives, the destruction of infrastructure (schools, hospitals etc.), and the desire for revenge on the part of those who are defeated.

\section{ii) Knowing when to end violent resistance is morally and} strategically as important as deciding to engage in it.

The plot against Hitler was a disastrous failure and the consequences were dire for all those involved. The armed struggle in South Africa, by contrast, undoubtedly contributed to the liberation of South Africa, even though it is difficult to gauge the extent to which it did so. But non-violent resistance was probably far more effective in ending the stalemate on the battlefield, opening up the possibility of negotiating an end to violent conflict, and initiating the process of national reconciliation and reconstruction. The country did not collapse into chaos and the destruction of infrastructure was limited. What was of crucial importance in bringing apartheid to an end was the recognition on the part of Mandela and de Klerk that South Africa could not be liberated or apartheid sustained by violence. So when to end the armed struggle became as important as the decision to begin it. Likewise, the political will to accept the need for fundamental change and negotiation rather than resort to further violence to maintain the status quo was critical. This requires moral and strategic discernment, and a political will that is committed to just peace-making rather than vengeance.

iii) It is only those genuinely committed to peace-making who have the moral authority to resort to violent resistance as a last resort. But can violent resistance and revolution be justified today given the cycle of violence that has already been unleashed in the twenty first century?

It is only those who are genuinely committed to working for peace and justice who command our respect when, with deep sorrow and reluctance and taking every step to limit its destructive consequences, they decide to

40 This is the translation in Bonhoeffer's Letters and Papers from Prison, 7. 
engage in violent resistance. It is only those who tread this path for the sake of the oppressed rather to achieve power and privilege for themselves, who deserve support and respect. Above all, it is only those who, in taking this fearsome step, are willing to risk their own lives, those who are prepared for self-sacrifice, who deserve our acclaim.

But given the escalation of war and the cycles of violence already evident in these opening decades of the twenty first century, and the terrible consequences that are engulfing the world as a result, we must seriously ask whether the use of violence can any longer be morally or even strategically justified in seeking to bring about political change. My conviction is that both Mandela and Bonhoeffer would agree with this sentiment given their commitment to peace-making and their sensitivity to the consequences of violent resistance even when it was strictly controlled as in the case of the armed struggle, and limited to the assassination of one man, as in the case of the plot against Hitler.

\section{Bibliography}

Bethge, Eberhard 2000. Dietrich Bonhoeffer: A Biography. Minneapolis: Fortress Press.

Bonhoeffer, Dietrich 2005. Ethics. Dietrich Bonhoeffer Works, vol. 6. Edited by Clifford J Green. Minneapolis: Fortress.

Bonhoeffer, Dietrich 2009. Berlin 1932-1933. Dietrich Bonhoeffer Works, vol. 12. Edited by Larry L Rasmussen. Minneapolis: Fortress.

Bonhoeffer, Dietrich 2010. Letters and Papers from Prison. Dietrich

Bonhoeffer Works vol. 8. Edited by John W de Gruchy. Minneapolis: Fortress Press.

Bracher, Karl D 1973. The German Dictatorship: The Origins, Structure and Consequences of National Socialism. London: Penguin Books.

Davenport, TRH, and Christopher Saunders 1977. South Africa: A Modern History. Johannesburg: Macmillan South Africa.

De Gruchy, John W, ed 1997. Bonhoeffer for a New Day: Theology in a Time of Transition. Grand Rapids: Eerdmans. 
De Gruchy, John W 2006. Being Human: Confessions of a Christian Humanist. London: SCM.

De Gruchy, John W 2010. 'Dietrich Bonhoeffer as Christian Humanist.' In Being Human, Becoming Human: Dietrich Bonhoeffer and Social Thought, edited by Jens Zimmerman and Brian Gregor, 3-24. Eugene, Oregon: Pickwick Press.

De Gruchy, John W. 'Beyers Naudé: South Africa’s Bonhoeffer?

Celebrating the centenary of the birth of Beyers Naudé - 1915-2015.' Stellenbosch Theological Journal vol. 1, no. 1 (2015): 79-98.

De Gruchy, John W and Steve de Gruchy 2004. The Church Struggle in South Africa: $25^{\text {th }}$ Anniversary Edition. London: SCM.

Foster, Dion. 'Mandela and the Methodists: faith, fallacy and fact.' Studia Historiae Ecclesiasticae 40, Supplement (2014): 87-115.

Gushee, David P 1994. The Righteous Gentiles of the Holocaust: A Christian Interpretation. Minneapolis: Fortress.

Heribert, Adam and Kogila Moodley 1993. The Negotiated Revolution: Society and Politics in Post-Apartheid South Africa. Berkeley, CA: University of California Press.

Kairos Palestine. Kairos-Palestine: A Moment of Truth: A Word of Faith, Hope and Love from the Heart of Palestinian Suffering. [Online]. Available: http://www.kairospalestine.ps/index.php/about-us/kairos-palestinedocument [Accessed 19 July, 2016].

Karis, Thomas G and Gail M Gerhart 1997. A Documentary History of African Politics in South Africa, 1882-1990: Nadir and Resurgence, 1964-1979. From Protest to Challenge, vol. 5. Pretoria: Unisa Press.

Kumalo, R. Simangaliso 2012. Pastor and Politicians: Essays on the Legacy of JL Die, the first President of the African National Congress. Pietermaritzburg: Cluster.

Luthuli, Albert 1962. Let my People Go! London: Collins.

Maanga, Godson S. 'The relevance and legacy of Nelson Mandela in the twenty-first century Africa: An historical and theological perspective.' African Journal of History and Culture vol. 5, no. 5 (2013): 96-113. 
Mandela, Nelson 1990. The Struggle is My Life: His Speeches and Writings Brought Together with Historical Documents and Accounts by Fellow Prisoners. London: IDAF Publications.

Mandela, Nelson 1994. Long Walk to Freedom: The Autobiography of Nelson Mandela. Johannesburg: Macdonald Purnell.

Meli, Francis 1988. A History of the ANC: South Africa Belongs to Us. Harare: Zimbabwe Publishing House.

Moses, John A. 'Dietrich Bonhoeffer as Conspirator Against the Hitler Regime: The Motivation of a German Protestant Revolutionary.' War and Society 17, no. 1 (1999): 28, n. 8.

Peires, Jeff. 'Agony and Ecstasy at the End of the Rainbow.' South African Historical Journal vol. 61, no.1 (2009): 178-86.

Rasmussen, Larry L 1972. Dietrich Bonhoeffer: Reality and Resistance. Nashville: Abingdon.

The Kairos Document 1986. Johannesburg: Institute for Contextual Theology. 